\title{
Incorporating Sustainability Issues Into The Financial Accounting Curriculum
}

\author{
Daniel L. Haskin, Texas A\&M University-Commerce, USA
}

Megan M. Burke, Texas A\&M University-Commerce, USA

\begin{abstract}
Changes in the views that society holds of capital allocation suggest that sustainability reporting needs to be incorporated into the financial accounting curriculum. This paper reviews the background and history of corporate social responsibility and sustainability reporting and discusses formation of the Sustainability Accounting Standards Board (SASB). The development of the SASB provides us with a framework to enhance the credibility and provide assurance for corporate social responsibility and sustainability reporting. A suggested outline for including sustainability reporting in a financial accounting course is presented.
\end{abstract}

Keywords: Corporate Social Responsibility; Sustainability; Financial Reporting; SASB; SEC; FASB

\section{INTRODUCTION}

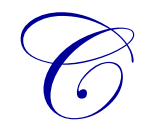
orporate social responsibility (CSR) and sustainability have become important and widely discussed issues over the last few decades. Sustainability, itself, is increasingly recognized as important, not only to society as a whole, but also to financial reporting. The Brundtland Report defined sustainability as, “... development that meets the needs of the present without compromising the ability of future generations to meet their own needs" (WCED, 1987). This paper is concerned with determining how sustainability relates to financial reporting and the incorporation of sustainability information into the teaching of financial accounting. A guide is now available to use for integrating sustainability issues into financial accounting classes. An organization called the Sustainability Accounting Standards Board (SASB) was founded in 2010 and issued a conceptual framework in 2013. The SASB has provided us with a wealth of material to use in integrating sustainability reporting into our financial accounting curriculum.

\section{Current Status}

Business schools have generally taught that the primary and perhaps the only goal of financial management is to maximize the value of the company's stock (increase the wealth of the shareholders). One interpretation of this objective is to increase the financial capital of the company. A broader view would incorporate other items (nonfinancial capital) such as environmental, social, and corporate governance issues into our definition of the goals of financial management. Sustainability is concerned with evaluating the non-financial capital of the company, and determining how the non-financial and financial capital affects the overall wealth of the company.

Financial accounting courses tend to focus on the objective of maximizing the financial capital of companies and mostly ignore the non-financial objectives. Financial accounting's main objective as stated in Statement of Financial Accounting Concepts No. 1 (FASB, 1978) is to provide information useful for making economic decisions. Consequently, financial accounting can be viewed as primarily concerned with the financial assets of an entity. Non-financial assets such as environmental and social capital are given little recognition in the financial accounting standards. Society and the economy have evolved to the point that more recognition is demanded by markets about other assets than financial assets for use in financial decision making.

The development of the SASB is a good starting place for incorporating other issues into the financial accounting curriculum. The SASB was founded in 2010. The founders felt that the current U.S. financial accounting system was adequate for its purpose of providing information for the markets to use in allocating capital, but that the current 
system was developed when the ability of a company to create wealth was mostly a function of its access to the financial capital markets.

The world has changed considerably as the financial markets have evolved over the last couple of hundred years. Sustainability issues, although not unknown, have been largely ignored by the financial industry and accounting educators. Sustainability issues concern the material, non-financial risks and opportunities in the marketplace today.

\section{What to Teach}

Historically, financial accounting courses have focused almost entirely on coverage of U.S. Generally Accepted Accounting Principles (GAAP). In the last few years, coverage of International Financial Reporting Standards (IFRS's) has been incorporated into the financial accounting curriculum. Because of the increased interest of society in general and the availability of CSR and sustainability accounting information, the time has come to include all material issues in the financial accounting curriculum.

The SASB believes that all of the major issues which are important for investors to use in making informed decisions should be included in Securities and Exchange Commission (SEC) filings and other published financial information. Consequently, these issues should be included in the financial accounting curriculum as well. The major justification for the inclusion of sustainability material in the financial accounting curriculum is the materiality of the information as discussed below.

\section{Lesson Plan}

Because of the latest developments, the SASB is an excellent starting point for introducing accounting students to CSR and sustainability reporting. The SASB is specific to financial accounting while CSR is a broader topic, so the focus should be on the SASB in the accounting curriculum. The SASB development has furnished us with a framework for studying CSR and sustainability.

Sustainability accounting could be offered as a special topics course and later developed into a regular accounting course or incorporated into a financial accounting course offered for accounting majors. Incorporation into the typical intermediate accounting course or an advanced financial accounting course would be a possibility. The suggested coverage could be from one week ( 3 hours of class time) up to an entire semester-long three hour course.

\section{Course Description}

The following course description could be used as a guide in establishing a course on CSR and sustainability accounting:

This course covers the influence of corporate social responsibility (CSR) and sustainability accounting on financial reporting in the United States. The recent development of the SASB framework has provided the accounting profession with a tool for the study of CSR and sustainability accounting. Topics covered in the course will be the definition of corporate social responsibility, the history of corporate social responsibility and sustainability accounting, metrics, history of the SASB, the conceptual framework of the SASB, the SASB's approach, materiality, processes of the SASB, Sustainable Industry Classification System (SICSTM), and the future of the SASB.

\section{Student Learning Outcomes}

1. The student will be able to demonstrate knowledge of CSR and the SASB.

2. The student will be able to discuss the influence of the SASB on the financial reporting industry.

3. The student will be able to identify and discuss the ten subject areas covered in the course. 


\section{Benefits to the University}

Including the study of CSR and the influence of the SASB in the accounting curriculum as described in this paper will keep the curriculum current. It is critical in the present business environment for accounting students to have a working knowledge of CSR and sustainability accounting. Accounting graduates, in line with the missions of most universities and business schools, would be more productive, ethical, and engaged citizens.

\section{Subject Areas}

This section presents a suggested listing of subject areas to be covered over sustainability accounting issues for presentation in a financial accounting course, and the following sections expand on the presentation of the suggested topics.

1. Definition of Corporate Social Responsibility

2. History of Corporate Social Responsibility and Sustainability Accounting

3. Metrics

4. History of SASB

5. Conceptual Framework

6. SASB's Approach

7. Materiality

8. Processes of SASB

9. Sustainable Industry Classification System $\left(\mathrm{SICS}^{\mathrm{TM}}\right)$

10. Future of SASB

\section{Definition of Corporate Social Responsibility}

Many definitions of corporate social responsibility (CSR) have surfaced over the last few years. One of the most complete definitions was offered by Carroll and Buchholtz in their 2003 book. They defined corporate social responsibility as the "economic, legal, ethical, and discretionary expectations that society has of organizations at a given point in time." (Carroll and Buchholtz, 2003). Economic responsibilities refer to society's expectation that organizations will produce reasonably priced goods and services that are needed and desired by customers. Organizations should operate efficiently and at a profit, In accordance with the classic definition of the role of management, organizations should keep shareholder's interests in mind. To fulfill their legal responsibilities, organizations should comply with the laws that govern competition in the marketplace. Ethical responsibilities refer to expectations that exceed legal requirements. Organizations should be concerned with fairness and justice. They should make proactive efforts to anticipate and meet the needs of society that are not formally enacted into law. Discretionary responsibilities require that organizations should be good citizens with involvement in such things as philanthropy, and should encourage employee involvement in worthwhile projects.

Another relevant definition of CSR was provided by Wilhelm Autischer (2003), who divided corporate social responsibility into the three dimensions of economic, social, and ecological. In the economic dimension, he maintains that CSR practices help not only the company adopting them, but the entire industry by raising the bar of expected behavior. Investors, seeing one company adopt CSR policies will be naturally inclined to invest in that company, having seen it demonstrate responsibility. Competitors in the same field, seeing the benefits of CSR, will adopt similar policies to remain competitive. The social dimension refers to internal changes that will occur as a company integrates CSR practices into its structure. Employees will be treated with more respect in CSR-conscious companies. Because employees will benefit from increased care from the company, they will transfer the positive influence to their homes and family and ultimately to society. Organizations can be ecologically responsible by adopting practices that attempt to secure a healthy and productive ecological environment for future generations and the future of the company, and by increasing economic efficiency through better ecological practices (Encyclopedia of Management, 2009). 


\section{History of Corporate Social Responsibility and Sustainability Accounting}

The concept of corporate social responsibility is a relatively new one, as the term has only been in wide use since the 1960s. The 1960s and 1970s were a period of much turbulence and change to society. The civil rights movement, consumerism, and environmentalism not only influenced society in general, but affected society's expectations of business. The concept of CSR is eloquently expressed in the following quote:

Based on the general idea that those with great power have great responsibility, many called for the business world to be more proactive in (1) ceasing to cause societal problems and (2) starting to participate in solving societal problems. Many legal mandates were placed on business related to equal employment opportunity, product safety, worker safety, and the environment. Furthermore, society began to expect business to voluntarily participate in solving societal problems whether they had caused the problems or not. This was based on the view that corporations should go beyond their economic and legal responsibilities and accept responsibilities related to the betterment of society. This view of corporate social responsibility is the prevailing view in much of the world today (Encyclopedia of Management, 2009).

A major influence on sustainability issues that preceded the SASB was the Global Research Initiative (GRI). GRI is an organization which promotes the use of sustainability reporting. It advocates the viewpoint that a sustainable global economy "should combine long-term profitability with ethical social justice and environmental care" (GRI, 2013). GRI is a non-profit organization founded in Boston in 1997. It was an offshoot of an organization called Coalition for Environmentally Responsible Economics (CERES). GRI issued a framework in 1998 that created an accountability mechanism to insure companies were including social, economic, and governance issues in their reporting. Although there is no formal relationship between GRI and SASB, GRI was a major influence on the founders of SASB.

\section{Metrics}

As CSR reporting is unregulated in the United States., a required framework for reporting does not currently exist. As a result, many different types and names of reports exists under the umbrella of CSR reporting, such as 'environmental reports', 'social reports', 'climate change reports', 'carbon reports', 'triple bottom line reports', and 'sustainability reports' among others. The common theme is that the CSR report is separate from the annual report and presents nonfinancial qualitative and quantitative data (Cecil, 2008). Cecil's study shows that there is a fifteenyear growth trend in voluntary CSR reporting in the United States. In 1991, only two companies issued CSR reports This number grew to 154 ten years later in 2001. Five years after that, in 2006, there were 230 companies that issued CSR reports in the United States. The growth rate of CSR reporting from 1991 through 2006 was 37\%

CSRHub is an online source that gives us an idea of how many companies issue CSR. It provides access to corporate social responsibility and sustainability ratings and information on about 15,000 companies from 135 industries in 129 countries. Managers, researchers, and activists use CSRHub to benchmark company performance and learn how stakeholders evaluate company CSR practices. (CSRHub.com).

Virtually all large U.S. companies now issue CSR reports. However, the value of the reports is the subject of much debate, because of the lack of assurance. Adhering to the SASB standards would enhance the credibility of CSR and sustainability information.

\section{History of SASB}

The SASB was founded in 2010 and officially launched in October of 2012. Its founders were a group of sustainability experts, thought leaders, and financial industry professionals. Its aim was to develop and distribute accounting standards that were industry-specific for use by U.S. publicly listed corporations and their investors concerning material sustainability issues. The SASB ultimately hopes to have its pronouncements incorporated into the SEC rules for publicly traded companies. The rules would govern what sustainability information the companies must disclose and how to disclose it. 


\section{Conceptual Framework}

The SASB issued its Conceptual Framework in October of 2013. The Framework is similar in intent to the Conceptual Framework of the FASB. Its aim is to set out 'the basic concepts and definitions behind the SASB's sustainability accounting standards (the SASB Standards) and serves as additional guidance for the adoption of the standards by corporations and the use of material sustainability information by investors" (SASB, 2013).

The SASB is primarily concerned with the role of environmental, social, and governance factors (ESG). A study by a United Nation's supported group has found that investors use ESG information for economic analyses, industry analysis, company strategy analysis, and valuation (United Nations, 2013). The SASB's mission is intended to bring the disclosure of ESG information into the main stream by including it in Form 10-K and other SEC filings.

The SASB standards are intended for the same companies who currently prepare financial statements regulated by the securities laws of the United States, and the beneficiaries of SASB Standards are defined as the hypothetical reasonable investor who invests for a variety of reasons such as asset valuation and generation of income.

\section{SASB's Approach}

Currently, financial accounting is primarily concerned with capital flows, which are expressed as numbers. The FASB, in its Conceptual Framework (FASB, 1978), states that assets, liabilities, and owner's equity of the entity should be expressed in financial terms. Accounting for non-financial assets is limited because there are generally no markets or good valuation techniques available. Consequently, even if ESG can be accounted for in terms of assets and liabilities, they cannot be valued properly for a good accounting treatment.

Because of these limitations, the SASB's approach to sustainability accounting uses "metrics or indicators" to ensure that investors have access to the "total mix" of needed information for decision making. The indicators are (SASB, 2013):

1. Attention to management of critical capitals;

2. Vulnerability to depletion or misuse of these capitals;

3. Scenario-planning regarding alternative resources;

4. Risks associated with mismanagement of certain environmental or social issues; and

5. Opportunities associated with global or industry sustainability challenges.

The SASB believes that the total mix of information will allow markets to set better prices by using information about all forms of capital. The SASB intends its work to be a complement to other required accounting disclosures, such as those issued by the FASB and the SEC. A more complete view of the company's capital and performance will be possible if sustainability information can be viewed in conjunction with required financial information (SASB, 2013).

\section{Materiality}

The SASB's primary support for requiring the inclusion of sustainability accounting information in SEC and other filings is based on the materiality of the sustainability accounting information. The SASB maintains that current laws and rules require sustainability information to be disclosed because the SEC requires that all material information be disclosed. Regulation S-K requires a description of, "any known trends or uncertainties that have had or that the registrant reasonably expects will have a material favorable or unfavorable impact on net sales or revenues or income from continuing operations. If the registrant knows of events that will cause a material change in the relationship between costs and revenues (such as known future increases in costs of labor or materials or price increases or inventory adjustments), the change in the relationship shall be disclosed" (SEC, Regulation S-K). The SASB believes that ESG information meets all of the above definitions of materiality and thus should be disclosed in Form 10-K. 
The FASB defined materiality as follows (FASB, 1978):

Information is material if omitting it or misstating it could influence decisions that users make on the basis of the financial information of a specific reporting entity. In other words, materiality is an entity-specific aspect of relevance based on the nature or magnitude or both of the items to which the information relates in the context of an individual entity's financial report. Consequently, the Board cannot specify a uniform quantitative threshold for materiality or predetermine what could be material in a particular situation.

The Supreme Court defined materiality as "a substantial likelihood that the disclosure of the omitted fact would have been viewed by the reasonable investor as having significantly altered the 'total mix' of information made available" (TSC, 1976).

\section{Processes of SASB}

The SASB follows a three-step process in developing standards. In the first phase, material sustainability issues and related metrics are identified. A research team then examines evidence of interest and evidence of financial impact for each industry.

In the second phase, Industry Working Groups (IWG's) composed of stakeholders, are organized to provide feedback on the issues identified in the first phase. The feedback is provided by responses to an online survey. The output of this phase is an Exposure Draft Standard.

In the third phase, the Exposure Draft Standard is released for a 90-day public comment period. The draft is available on the SASB's website and any member of the public can provide feedback. The feedback is analyzed and incorporated into the draft standard, and after review, a Provisional Draft Standard is published and made available to the public. All of the standards will be considered provisional until the complete set for all industries is complete and is reviewed by the American Standards Institute.

\section{Sustainable Industries Classification System}

The SASB is initially developing standards for 89 industries in 10 sectors. The standards are designed to be appropriate for use in 10-K forms. The ten sectors are listed below and are followed by the industries included in that sector (SASB, 2013):

1. Health Care-Biotechnology \& Pharmaceuticals, Medical Technology, and Health Care Providers

2. Financials-Banking \& Investment Banking, Specialty Finance, and Insurance

3. Technology \& Communication-Technology, Semiconductors, Telecommunications, and Internet Media \& Services

4. Non-Renewable Resources-Oil \& Gas, Coal, Metals \& Mining, and Construction Materials

5. Transportation-Automobiles, Air Transportation, Marine Transportation, and Land Transportation

6. Services-Consumer Services, Hospitality \& Recreation, and Media

7. Resource Transformation-Chemicals and Industries

8. Consumption-Food, Beverages, Tobacco, and Retailers

9. Renewable Resources \& Alternative Energy-Alternative Energy and Forestry \& Paper

10. Infrastructure-Utilities, Waste Management, Infrastructure, and Real Estate

\section{Future of SASB}

The SASB aims to have the relevant disclosures included in the Management Discussion and Analysis (MD\&A) section of Form 10-K in a section titled "Sustainability Accounting Standard Disclosures." The justification for the inclusion in MD\&A comes from SEC Release Nos. 33-8056; 34-45321: 
We also want to remind registrants that disclosure must be both useful and understandable. That is, management should provide the most relevant information and provide it using language and formats that investors can be expected to understand. Registrants should be aware also that investors will often find information relating to a particular matter more meaningful if it is disclosed in a single location, rather than presented in a fragmented manner throughout the filing.

If the SASB succeeds in having these standards included in Form 10-K, it will be a great step forward for sustainability reporting.

An important question regarding the future of the SASB concerns the survival of the SASB. Will the SASB survive as a successful, standards-setting body or will its functions be absorbed by the FASB or SEC? It seems certain that the demand for reporting of sustainability information is here to stay, so the future of the SASB seems assured unless its role is preempted by the FASB, the IASB, the SEC, or some other existing authoritative body.

\section{CONCLUSION}

Accounting educators should integrate CSR and sustainability issues into the existing financial accounting curriculum using the SASB materials as the major resource. As CSR and sustainability reporting are currently unregulated in the U.S., the SASB framework provides us with a good platform for study. In the future, financial reporting should endeavor to include all material items in Form 10-K. The SASB has provided a framework for presenting sustainability information in published reports. This information should greatly benefit the stakeholders who use financial reports.

\section{AUTHOR BIOGRAPHIES}

Daniel L. Haskin, Ph.D., CPA, is an Assistant Professor of Accounting at Texas A\&M University-Commerce. His research interests include financial accounting, auditing, and accounting education.

Email: Daniel.Haskin@tamuc.edu.

Megan M. Burke, Ph.D., CPA is an Assistant Professor of Accounting at Texas A\&M University-Commerce. Her research interests include taxation and accounting education. Email: Megan.Burke@tamuc.edu.

\section{REFERENCES}

Carroll, A.B., and A.K. Buchholtz. Business and Society: Ethics and Stakeholder Management. 5th ed. Australia: Thomson South-Western (2003).

Cecil, Lianna "Corporate Social Responsibility Reporting the United States," McNair Scholars Research Journal: Vol. 1: Iss. 1, Article 6. (2008)

"Corporate Social Responsibility." Encyclopedia of Management. Encyclopedia.com: (2009) http://www.encyclopedia.com/doc/1G2-3273100059.html.

CSRHub.com, Homepage (2015).

FASB, Statement of Financial Accounting Concepts No. 1, Objectives of Financial Reporting by Business Enterprises, Norwalk, CT: FASB (1978).

GRI, Global Reporting Initiative, Sustainability Reporting Guidelines, Amsterdam: GRI (2013).

SASB, Conceptual Framework, San Francisco: SASB (2013).

SEC, Regulation S-K, 17 CFR 229.303(a) (3) (Item 303).

SEC [Release Nos. 33-8056; 34-45321; FR-61] Commission Statement about Management's Discussion and Analysis of Financial Condition and Results of Operations.

TSC Indus. V. Northway, Inc., 426 U.S. 438, 449 (1976).

United Nations, How Investors Are Addressing Environmental, Social and Governance Factors in Fundamental Equity Valuation, United Nations -supported Principles for Responsible Investment (PRI), (2013).

World Commission on Environment and Development (WCED). Our Common Future. Oxford: Oxford University Press, (1987). 
NOTES 